\title{
The palaeogeographic setting and the local environmental impact of the 130 ka Falconiera tuff-cone eruption (Ustica island, Italy)
}

\author{
Sandro de Vita ${ }^{\star}$, Franco Foresta Martin ${ }^{2}$ \\ ${ }^{1}$ Istituto Nazionale di Geofisica e Vulcanologia, Sezione di Napoli Osservatorio Vesuviano, Napoli, Italy \\ ${ }^{2}$ Laboratorio Museo di Scienze della Terra, Ustica, Palermo, Italy \\ Article history \\ Received July 14, 2016; accepted February 03, 2017. \\ Subject classification: \\ Volcanic rocks, Geomorphology, Tuff-cone, Fossils, Sediments.
}

\begin{abstract}
This research focuses on the effects of the last eruption at Ustica, which formed the Falconiera tuff-cone at around $130 \mathrm{ka} B P$ in the north-eastern tip of the island. This eruption was mainly explosive and phreatomagmatic, emplacing a series of pyroclastic surge beds that formed an asymmetric tuff cone. This is the most easily recognizable volcanic edifice on Ustica, although its north-eastern sector has been partially eroded. A section of the feeding conduit is exposed northward, and is composed of lavas that fed the last stages of the eruption characterized by an intracrateric lava lake and a Strombolian scoria-fallout deposit. The eruption occurred during Upper Pleistocene Marine Isotopic Substage 5.5, a warm period characterized by a high sea-level stand ( $6 \pm 3 \mathrm{~m}$ above the present sea level in stable areas) and the diffusion of subtropical flora and fauna across the Mediterranean sea. This eruption slightly modified the morphology of Ustica, but impacted both marine and terrestrial environments, burying beach deposits rich in mollusk shells (i.e. Strombus bubonius, Conus testudinarius, Brachidontes puniceus), colonies of corals (Cladocora caespitosa) and subaerial plants (Chamaerops humilis). These organisms, found in some cases in their life position, along with other lines of evidence, provide information on the palaeogeography of this sector of the island at the time of the eruption and on the local impact of this event on the environment.
\end{abstract}

\section{Introduction}

The island of Ustica is the top of a vast submerged volcanic complex that rises more than $2,000 \mathrm{~m}$ from the bottom of the Tyrrhenian Sea on thinned continental crust [15-20 km; Giese and Morelli, 1973]. It is situated $60 \mathrm{~km}$ north of the Sicily coast, west of the Aeolian arc, and a few km east of the E-W trending Anchise seamount (Figure 1). The emergent part of Ustica volcano covers an area of less than $10 \mathrm{~km}^{2}$ and reaches a maximum elevation of $248 \mathrm{~m}$ asl It is mainly composed of volcanic rocks, and subordinately of marine and continental sedimentary deposits. Volcanic rocks are the product of both subaqueous and subaerial effusive and explosive eruptions [Romano and Sturiale, 1971; Cinque et al., 1988; de Vita, 1993; de Vita et al. 1995; 1998]. Marine sedimentary rocks consist of clayey sands, organogenic and detrital fossiliferous limestones, and carbonate concretions. They were sedimented during Middle-Upper Pleistocene sea level high-stands that were related to glacio-eustatic movements that also generated five orders of marine terraces [de Vita and Orsi, 1994]. Continental sedimentary rocks are detrital aprons, sometimes pedogenized, landslide deposits and detrital fans, related to the more recent geomorphological evolution of the island [de Vita, 1993].

The Ustica volcanic rocks have a Na-alkaline affinity, ranging in composition from alkali-basalts to alkali-trachyte, with a compositional gap in the field of benmoreite [55-60 wt \% $\mathrm{SiO}_{2}$; de Vita, 1993; Peccerillo, 2005]. Mafic rocks, in particular, cross the line that separates the subalkaline and the alkaline fields and display a transitional character [Peccerillo, 2005]. Moreover Ustica basalts are characterized by incompatible elements and Sr-isotope ratios that are intermediate between intraplate basalts from Pantelleria and calc-alkaline mafic rocks from Aeolian islands [Cinque et al., 1988]. This led Trua et al. [2003] to conclude that the Ustica magmas were generated by an intra-plate type mantle, contamined by subduction fluids or melts during the fast rollback of the Ionian slab. The origin of Ustica volcanism has been related to the activation of left-transtensional deep faults, linked to the deformational events that accompanied the anticlockwise rotation of the Italian peninsula and the opening of the Tyrrhenian basin, in the course of the 


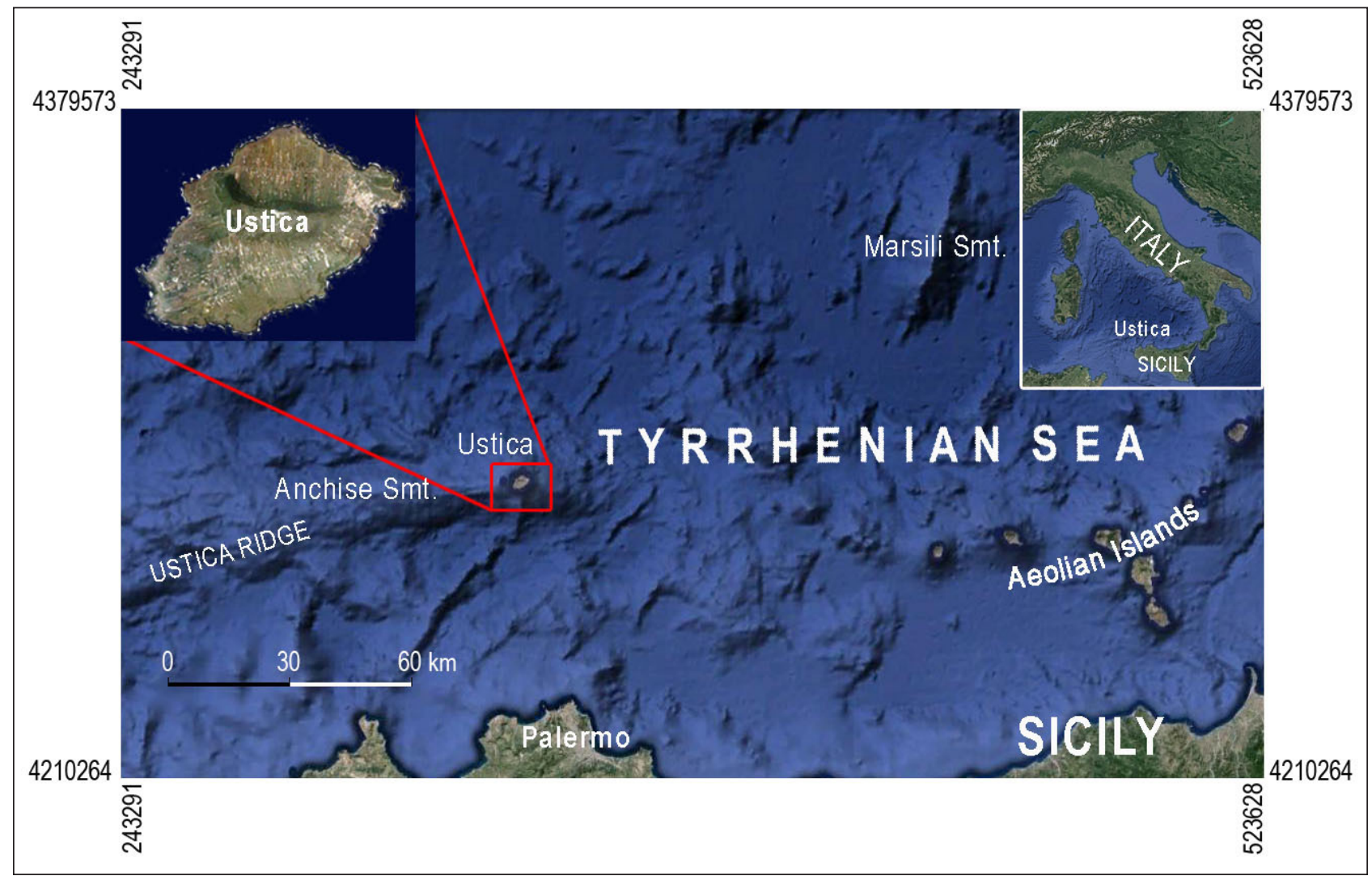

Figure 1. Morphological map of Southern Tyrrhenian Sea (modified after Google Earth; Image Landsat, Data SIO, NOOA, US Navy, NGA, GEBCO, Map Data (C) 2016). Coordinate system UTM WGS84, 33S. Left top-angle: Ustica Island image from the same source.

complex interaction between the African and Eurasian plates [de Vita et al., 1995].

A Pleistocene age has been assumed for the birth of the Ustica volcanic complex [Barberi et al., 1969; Barberi and Innocenti, 1980], whereas more recent stratigraphic, structural and geochronological studies demonstrate that the exposed rocks were formed between 750 and $130 \mathrm{ky}$ [de Vita et al., 1998]. The present morphology of the island is the result of the prolonged interplay between volcanism, tectonism, eustatism and exogenous morphodynamic processes, that generated volcanic edifices and structures, and level surfaces, displaced at variable height above sea level, and produced different deposits and erosional features.

This paper focuses on the effects of the last eruption on Ustica, which formed the Falconiera tuff-cone at around $130 \mathrm{ka}$ BP in the north-eastern tip of the island. This eruption slightly modified the Ustica morphology, but impacted on both marine and terrestrial environments, burying beach deposits rich in mollusk shells, colonies of corals and subaerial plants. The discovery of these organisms, in some cases still in their vital position, along with other geological, volcanological and geomorphological evidence, allowed the reconstruction of the palaeogeography of this sector of the island at the time of the eruption, and the local environmental impact of this event.

\section{Geological framework}

Volcanism at Ustica started with the activation of a series of submarine vents along ENE-WSW trending, deep transtensional faults that allowed magmas to quickly reach the surface, directly from their mantle source, feeding effusive eruptions [Barberi et al., 1969; Barberi and Innocenti, 1980; de Vita, 1993]. Following this, the activity concentrated into a main seamount, whose products reached the surface in the Middle Pleistocene, making Ustica the only volcano of anorogenic origin that has emerged from the Southern Tyrrhenian Sea (Figure 2). The emergence of the island coincided with the birth of the Mt. Guardia dei Turchi subaerial basaltic stratovolcano at about $520 \mathrm{ka}$ [de Vita et al., 1998; Figure 2], whose initial eruptions occurred subaqueously and formed pillow-lava flows. Subaerial volcanic activity continued with the formation of the Mt. Costa del Fallo basaltic tuff-cone, which is the second highest peak on the island, and a series of moderately explosive and effusive eruptions, the most recent of which occurred at $475 \mathrm{ka}$, along the western flank of Mt. Costa del Fallo [de Vita et al., 1998; Figure 2]. After a 50 ky long period of quiescence, during which magma differentiated in a shallow 


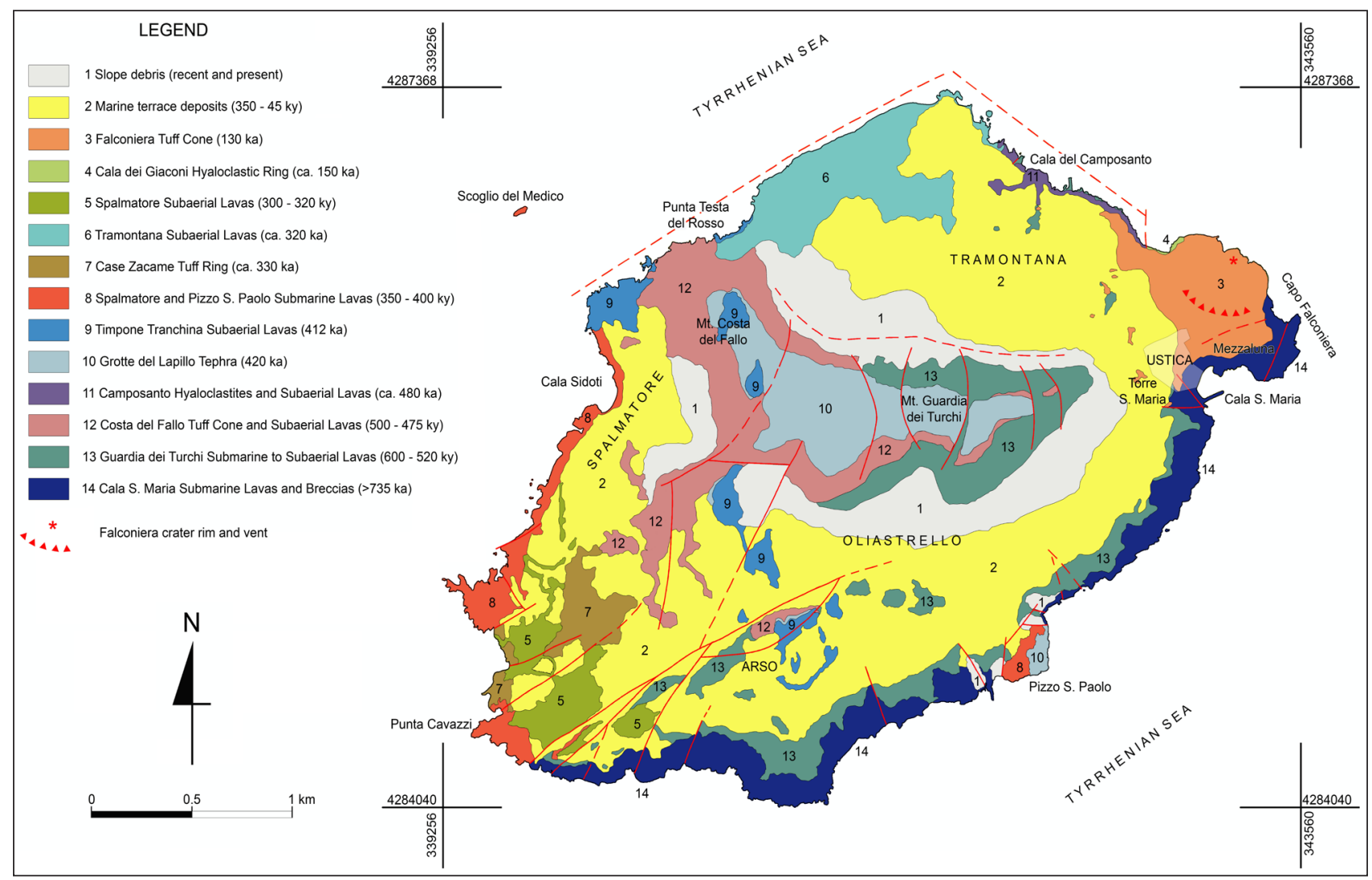

Figure 2. Geological sketch map of Ustica island (modified after de Vita, 1993). Coordinate system UTM WGS84, 33S.

magma chamber, volcanism restarted at $425 \mathrm{ka}$ with the sub-Plinian eruption of the Grotte del Lapillo Tephra [de Vita et al., 1998; Figure 2]. This is the only episode during which trachytic magma was erupted, although shallow intrusions along the southern coast and in the northern offshore [Bellia et al., 2000] were most likely produced by the same magmatic episode. The explosive eruption took place in the present Tramontana plain and was associated with the formation of a small caldera in the northern sector of the island. The tephra produced by this eruption blanketed almost of the island, and formed a thick sequence of pumice lapilli and ash, emplaced by fallout and pyroclastic density currents [de Vita, 1993; de Vita et al., 1995; 1998]. Basaltic magmas were erupted during the following volcanic activity, which produced at least twelve magmatic and phreatomagmatic effusive and explosive eruptions. Most of the deposits generated by these eruptions are exposed in the western and northern sectors of the island and are composed of both subaqueous and subaerial lava flows, hyaloclastites and tuff-ring-forming pyroclastic surge beds (Figure 2). Volcanic activity on the island ceased at around $130 \mathrm{ka}$, with the explosive Falconiera phreatomagmatic eruption and the formation of an asymmetric tuff cone, which is the most easily recognizable volcanic edifice (Figure 3).

Throughout Ustica's volcanic history, there were several overlapping cycles of marine transgression and regression, resulting from Middle-Upper Pleistocene glacio-eustatic movements. The sea-level stands related to these oscillations generated typical sedimentary terraces, which were later displaced by tectonism at variable heights from their original position. Five orders of level surfaces have been identified at heights ranging from about $100 \mathrm{~m}$ asl for the oldest and highest terrace, to $5 \mathrm{~m}$ asl for the most recent and lowest one [Table 1; de Vita and Orsi, 1994; de Vita et. al., 1998].

The main deformational lineaments still preserved on Ustica, trend E-W and NE-SW. They were produced by variable tectonic phases, the oldest of which seems to have generated the E-W trending fault system, along which also the older Anchise seamount was generated (Figure 1). Almost all the volcanic vents of the island are aligned along a N60E trending lineament, which represents, together with an associated N25E trending system of en échelon faults, the response to a regional state of stress, characterized by sinistral transtension [de Vita et al., 1995]. NW-SE and N-S trending fault systems are subordinated and associated to a less relevant volcanic activity [de Vita, 1993]. The occurrence of marine terraces of variable age at decreasing elevation from the oldest to the youngest, helps in defining the amount of uplift recorded by the island: it has to have been no more than $120 \mathrm{~m}$, at least since the formation of the oldest level surface at $350 \mathrm{ka}$. During this period relative displacement 


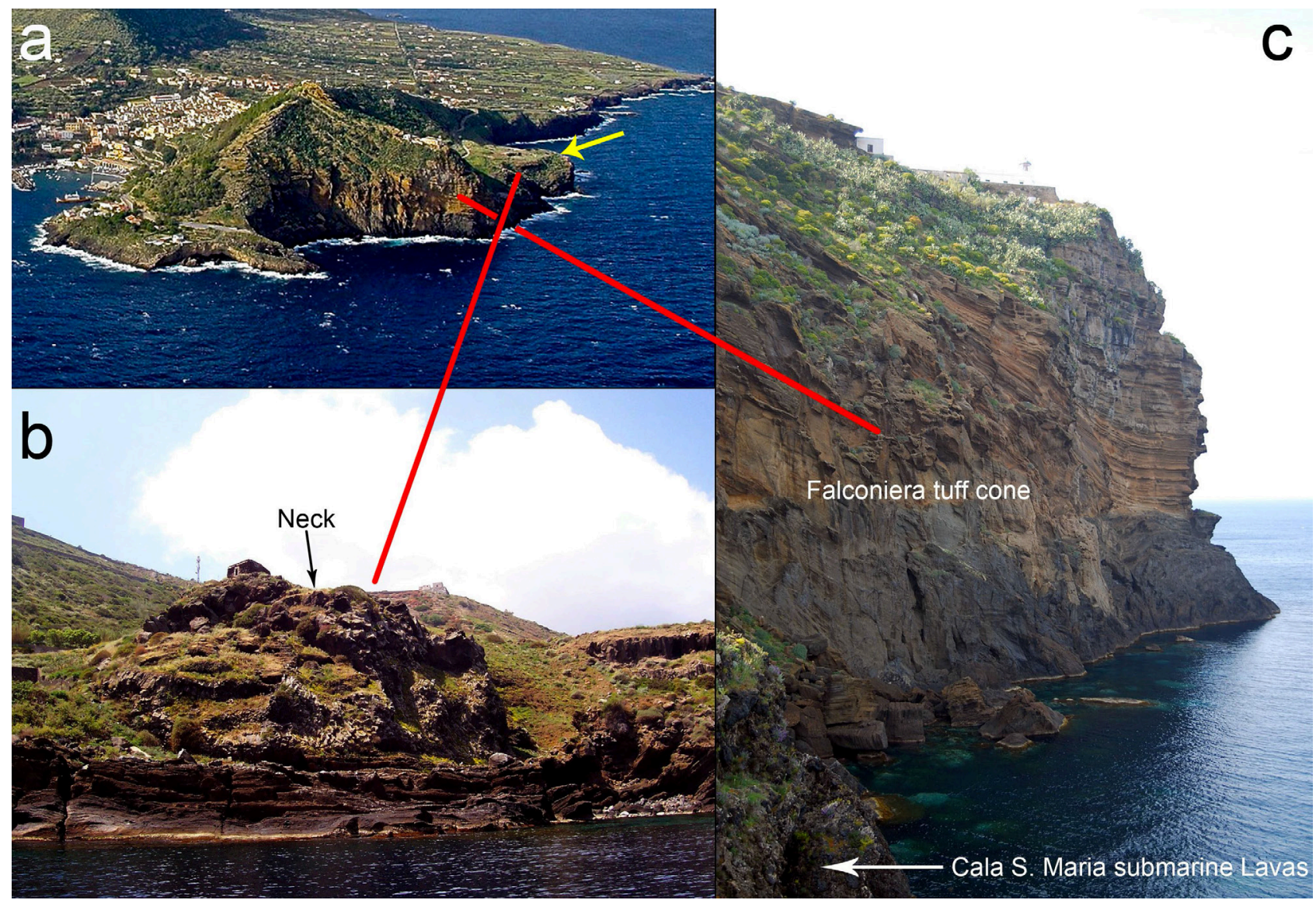

Figure 3. a) The Falconiera Tuff Cone, as seen from the east, with the level surface at $30 \mathrm{~m}$ asl (yellow arrow); b) the neck of the edifice; c) the variable degree of palagonitization of the Falconiera deposits, evidenced by colour differences.

\begin{tabular}{lcc}
\hline Order & Height $(\mathbf{m}$ asl $)$ & Age $(\mathbf{k a})$ \\
\hline I & $80-120$ & 350 \\
II & $40-60$ & $240 \pm 35$ \\
III & 30 & $132 \pm 6$ \\
IV & 10 & 105 \\
V & 5 & 80 \\
\hline
\end{tabular}

Table 1. Elevation and age of the marine terraces of Ustica island [after de Vita and Orsi, 1994].

of parts of the entire complex accompanied the general uplift of the island, mostly along the same N60E trending fault planes [de Vita et al., 1995].

\section{The Falconiera tuff-cone}

In this section are described the results of a detailed geological survey, carried out on the island in order to define the areal distribution of the Falconiera tuff-cone deposits and their stratigraphic relationships with the other exposed units.

\subsection{Morphology and stratigraphic position}

The Falconiera tuff-cone is a rather well preserved volcanic edifice (Figure 3a), whose original shape, as deduced from the geometry of the pyroclastic beds that built it up, was an asymmetric cone with higher southern portions. The northern part of the cone is partially missing, likely due to normal erosional processes and syn-depositional collapses, caused by the gravitational instability related to its rapid growth and the action of the sea-waves. The latter generated a level surface, which is presently at an elevation of about 30 $\mathrm{m}$ asl, and exposes the neck of the edifice at the bottom of the crater (Figure $3 \mathrm{~b}$ ). The Falconiera tuff-cone reaches a maximum elevation of $158 \mathrm{~m}$ asl Its products cover less than $1 \mathrm{~km}^{2}$ and extend northwestward to Cala del Camposanto, and southward to Cala Santa Maria, and partially underlie Ustica village. Other outcrops of limited areal extent are exposed at a distance up to $750 \mathrm{~m}$ in the Tramontana plain and in the western peripheral part of the village, up to Torre Santa Maria (Figure 2). The deposits of the Falconiera tuff-cone are the youngest volcanic products on the island, which unconformably overlie all the oldest units, through the interposition of a paleosol in the westernmost exposures, or marine and beach deposits toward north and south-southeast (Figure 4). Marine deposits are composed of loose to weakly cemented, plane-parallel to cross-stratified volcanic sand, with abundant fragments 
of shells (lamellibranches and gasteropods) and angular fragments and pebbles of basaltic lavas and tuffs. Beach deposits are mainly loose or weakly cemented gravels and sandy gravels, with flattened and imbricated pebbles of basaltic lavas, conglomerates and tuffs, and interbedded lenses and pockets of fine-to-coarse sands with abundant remnants of marine organisms (whole shells and fragments of lamellibranches and gasteropods), and dispersed blocks of basaltic lavas and conglomerates with volcanic clasts, detrital and organogenic sandy matrix and carbonatic cement. Marine deposits characterized by identical faunal association have been found above the Falconiera tuff-cone deposits in the Mezzaluna outcrop [Buccheri et al., 2014]. Both the lowermost and uppermost marine deposits have been correlated to the Upper Pleistocene Tyrrhenian Stage (Marine Isotopic Substage 5.5) on the basis of their fossil contents [Ruggeri and Buccheri, 1968; Buccheri et al., 2014]. All along the western outcrop area, the Falconiera deposits are overlain by reworked and cultivated, humified slope-debris deposits.

\subsection{The volcanic succession}

The Falconiera tuff-cone is mainly composed of thinly-stratified and lithified pyroclastic surge beds, characterized by variable thicknesses and grain-sizes, intercalated at different heights with scoria fall deposits. Lithification is due to the palagonitization of the volcanic glass, which has affected the edifice in a variable degree (Figure 3c). The Falconiera deposits have a maximum thickness of about $130 \mathrm{~m}$ close to the top of the hill and thin rapidly radially from the vent area. Coarser-grained beds are 10-20 centimeters thick on average, and thin slightly with distance from the vent. They are usually massive and composed of a coarse-ash matrix with dispersed abundant, lapilli-sized black scoriae and lithic fragments (both cogenetic or accessory). Finer-grained beds are a few centimeters thick and are composed of plane-parallel to cross stratified layers of ash and fine-ash with abundant coarse-ash to lapilli-sized black scoriae and lithic fragments. Scoria fallout deposits are laterally discontinuous (lensoid), due to the erosion by pyroclastic density currents. These deposits are poorly sorted and composed of lapilli to bomb-sized, well vesiculated, black scoriae, poorly porphyritic with small, clear phenocrysts of olivine. A very small amount of lithic fragments has been observed. Impact sags from ballistically emplaced blocks $(5-40 \mathrm{~cm}$ in diameter) are very common. The dips of the beds are quaquaversal, with inward high-angle and outward low-angle dip directions that vary from the inside toward the outside of the edifice across the cra-

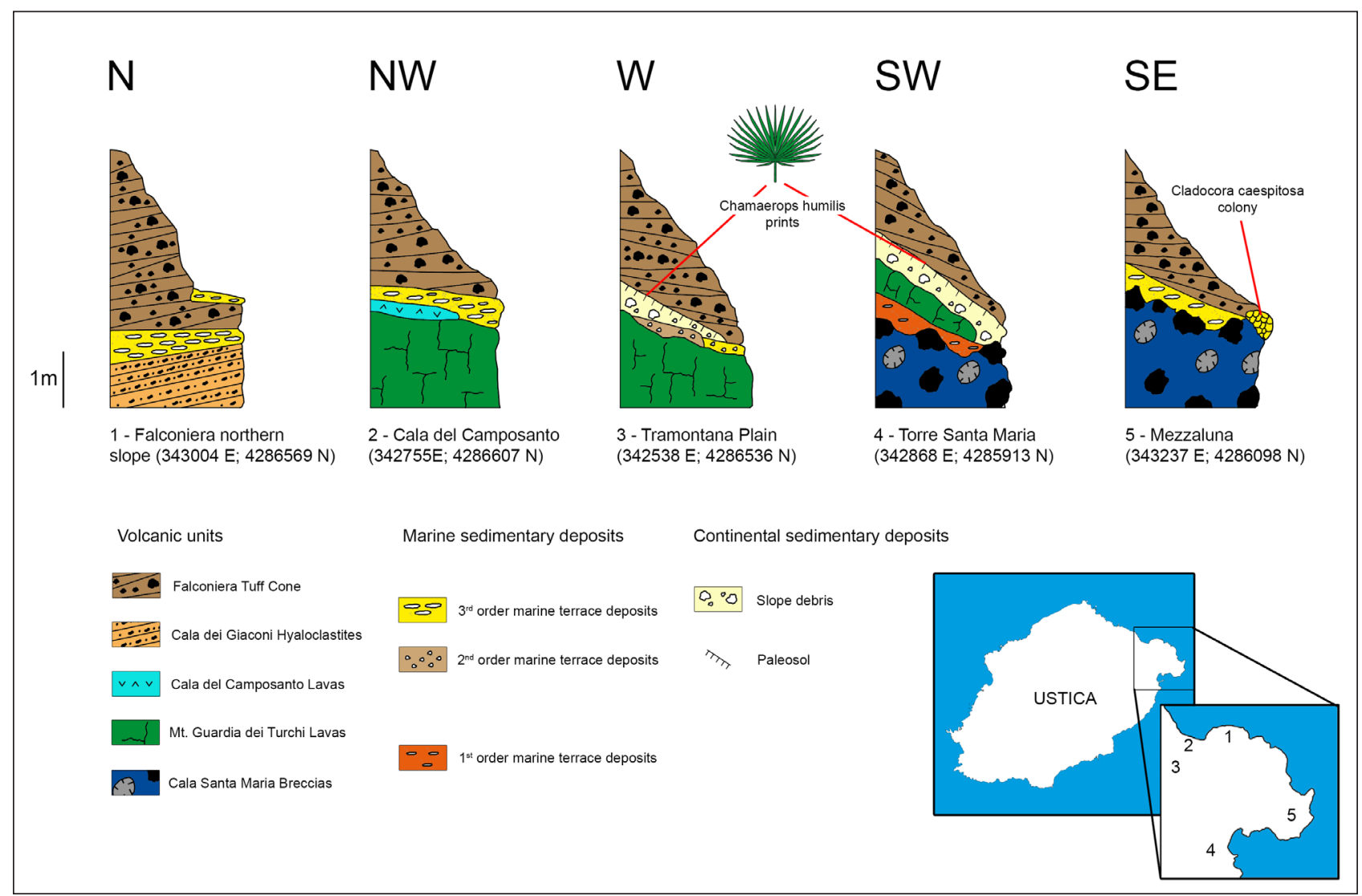

Figure 4. Scheme of the stratigraphic sequences exposed in the studied sections. Coordinate system UTM WGS84, 33 S. 
ter rim. The neck of the edifice is exposed at the bottom of the crater, and is composed of a columnar-jointed lava overlying the first strata of the tuff-cone close to the vent. The lava continues downward into the volcanic conduit, as a feeding dike with intrusive contacts. Lavas are light-grey in colour and porphyritic with clear olivine phenocrysts in a microcrystalline groundmass. An identical columnar jointed lava body, characterized by the same texture and mineralogy, is exposed a few tens of meters westward, in a sub-horizontal, tabular arrangement. These lavas are overlain by a discontinuous deposit of welded black scoriae of variable thickness.

The erupted products are hawaiitic in composition, with a $\mathrm{SiO}_{2}$ content that varies from $46.36 \%$ in the pyroclastic deposits to $48.69 \%$ in the lavas erupted during the last stage of the eruption [de Vita, 1993].

\section{The third order marine terrace of Ustica}

The third order marine terrace is related to an Eutyrrhenian transgressive-regressive cycle that correla- tes to the Marine Isotopic Stage (MIS) 5.5. It is widely developed along the Tramontana Plain, from the eastern end of Cala del Camposanto to Punta Testa del Rosso, with an average gradient of $3 \%$. The terrace extends between 30 and $40 \mathrm{~m}$ of elevation asl and it is bordered by a gently dipping slope, which connects to the lowermost and more recent marine terrace. The marine ingression responsible for the formation of the terrace, left a 2-6 m thick detrital deposit, mainly composed of clayey sands with rounded marine pebbles, and boulders that probably originated through the dismantling of the Mt. Guardia dei Turchi northern cliff that bordered the terrace. The inner margin of the terrace is not exposed as it was later buried by the slope debris of this cliff. The lower surface of the terrace is cut on a rocky substratum, composed of lava flows belonging to the Mt. Guardia dei Turchi and Cala del Camposanto units [Figure 2; de Vita et al., 1998].

On the opposite side, along the southern slope of the Falconiera tuff-cone, the Eutyrrhenian marine transgression has left a fossiliferous beach deposit in the
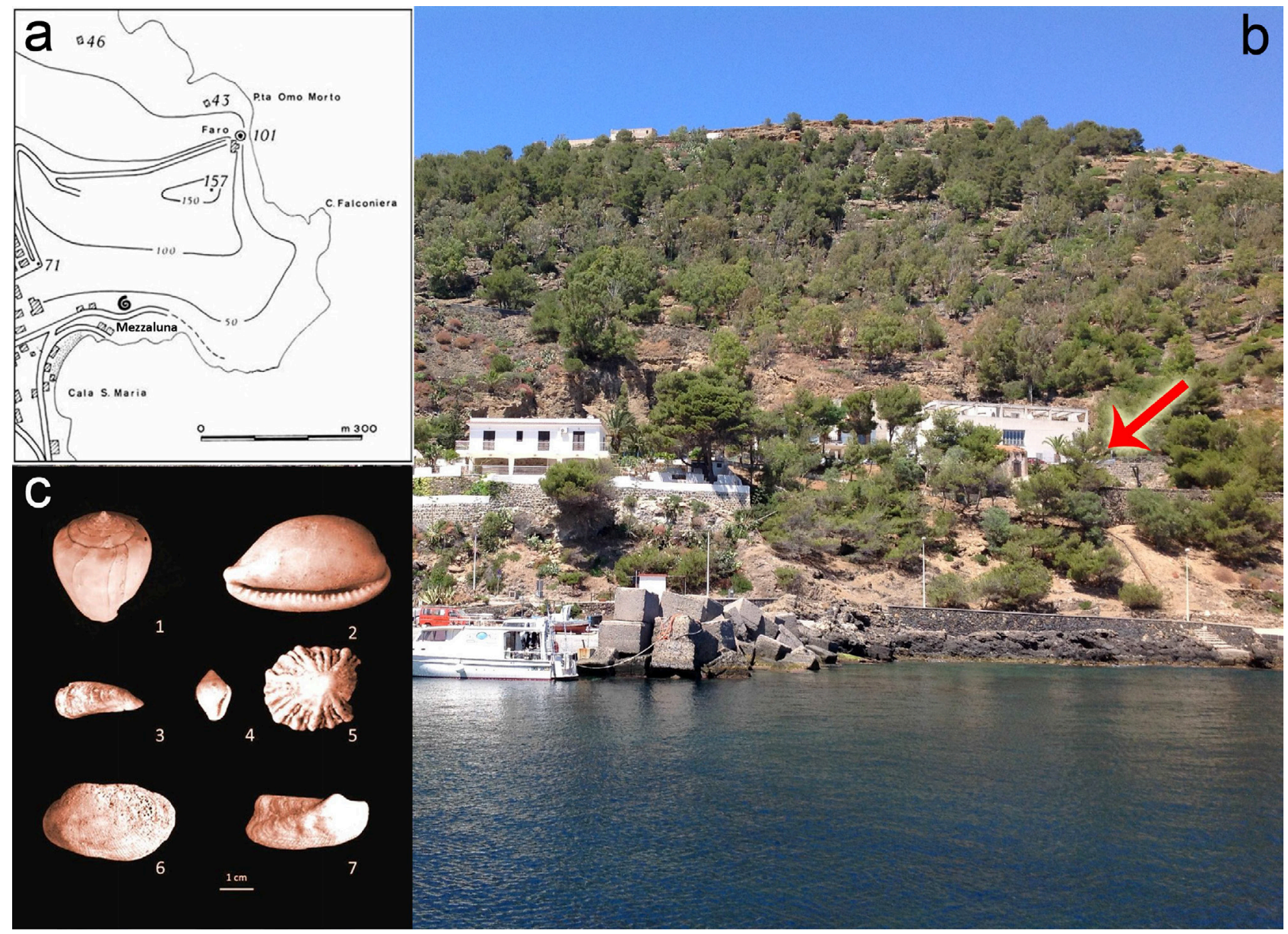

Figure 5. a) Location of the marine Tyrrhenian fossiliferous deposits at Mezzaluna [after Ruggeri and Buccheri, 1968]; b) the southern slope of the Falconiera Tuff Cone. The red arrow indicates the position of the beach deposit at about $30 \mathrm{~m}$ asl; c) significant specimens of the malacofauna [1-Conus testudinarius Hwass; 2- Luria lurida; 3- Brachidontes puniceus; 4- Columbella rustica; 5- Patella ferruginea; 6- Barbatia barbata; 7- Arca noae; after Buccheri et al., 2014]. 


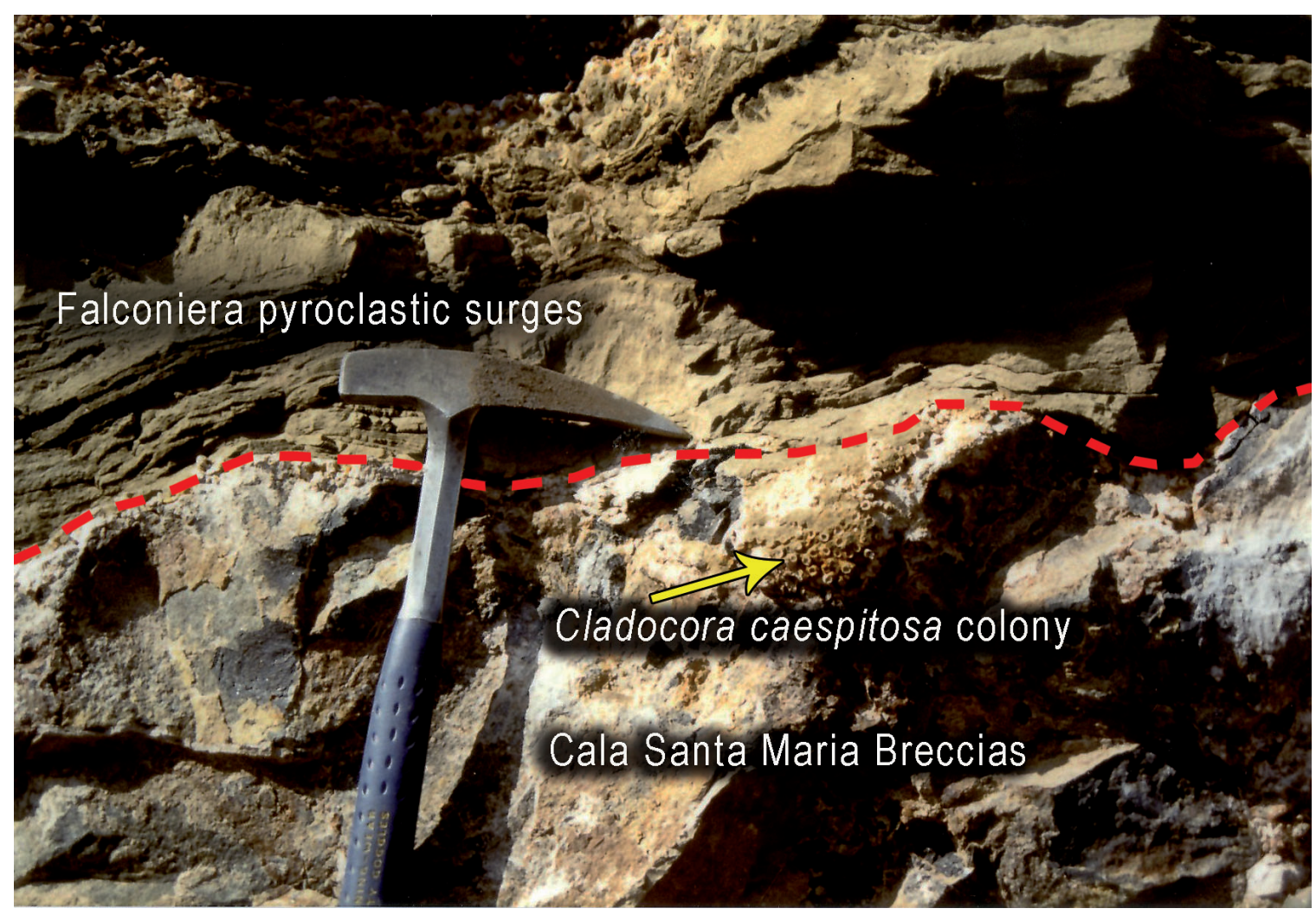

Figure 6. The Cladocora coespitosa colony buried under pyroclastic deposits of the Falconiera Tuff Cone at Mezzaluna (southern slope of the Falconiera Tuff Cone).

Mezzaluna site, at an altitude of about $30 \mathrm{~m}$ asl [Figures 5a - b; de Vita and Orsi, 1994; Buccheri et al., 2014].

The Mezzaluna fossil deposit is a very significant paleontological site, characterized by the presence of a typical, tropical-sea malacofauna, first discovered by Ruggieri and Buccheri [1968]. It contains corals, algae and mollusks such as Strombus bubonius, Conus testudinarius, Brachidontes puniceus and other species that are usually included in the Senegalese fauna [Figure 5c; Buccheri et al., 2014]. This malacofauna colonized the Mediterranean during the last interglacial, over a long period when the climate was warm, corresponding to the whole Tyrrhenian stage, which had its warmest peak during the Eutyrrhenian chronostratigraphic subunit [Kindler et al., 1997; Ferranti et al., 2006], between 132 and $125 \mathrm{ky}$. This subunit corresponds to the MIS 5e [Shackleton and Opdike, 1973], today referred as MIS 5.5, which was characterized by a high sea-level stand $[6 \pm 3 \mathrm{~m}$ above the present sea level in stable areas; Ferranti et al., 2006].

In the same place, at a lower altitude with respect to the previously described fossiliferous beach deposit (about 10-15 m asl), a colony of Cladocora Caespitosa corals has been found in its life position on a steeply dipping reef, covered by the basal layers of the Falconiera tuff-cone (Figure 6). U/Th radiometric dating performed on some specimens of these corals have in- dicated an age of about $132 \mathrm{ka}$ [de Vita and Orsi, 1994; de Vita et al., 1998].

\section{The Chamaerops humilis leaf prints}

The geological survey carried out on the island revealed the presence of a widespread paleosol at the base of the Falconiera tuff-cone deposits in their westernmost outcrops. In the Tramontana plain this paleosol developed on a detrital substratum composed of marine deposits, related to the previous, Middle-Crotonian, transgressive-regressive cycle [de Vita, 1993; de Vita and Orsi, 1994; de Vita et al., 1998]. In the western periphery of Ustica village the paleosol is developed on debris-slope deposits, representing the geomorphological evolution of the eastern slopes of Mt. Guardia dei Turchi volcano. In two outcrops the basal pyroclastic surge deposits contain abundant leaf prints, belonging to dwarf palm bushes, classified as Chamerops humilis [L. Sadori pers. comm.]. The Chamaerops humilis is the only species of its genus and is native to the Western Mediterranean [Fedriani and Delibes, 2011]. Its present distribution is restricted to the area of origin [Medail and Quezel, 1996], both on the European side (where it is the only native palm species) and on the African side. However, at the time of the Falconiera eruption it had its maximum areal extent (Figure 7).

Chamaerops humilis is small, multi-stemmed, and 


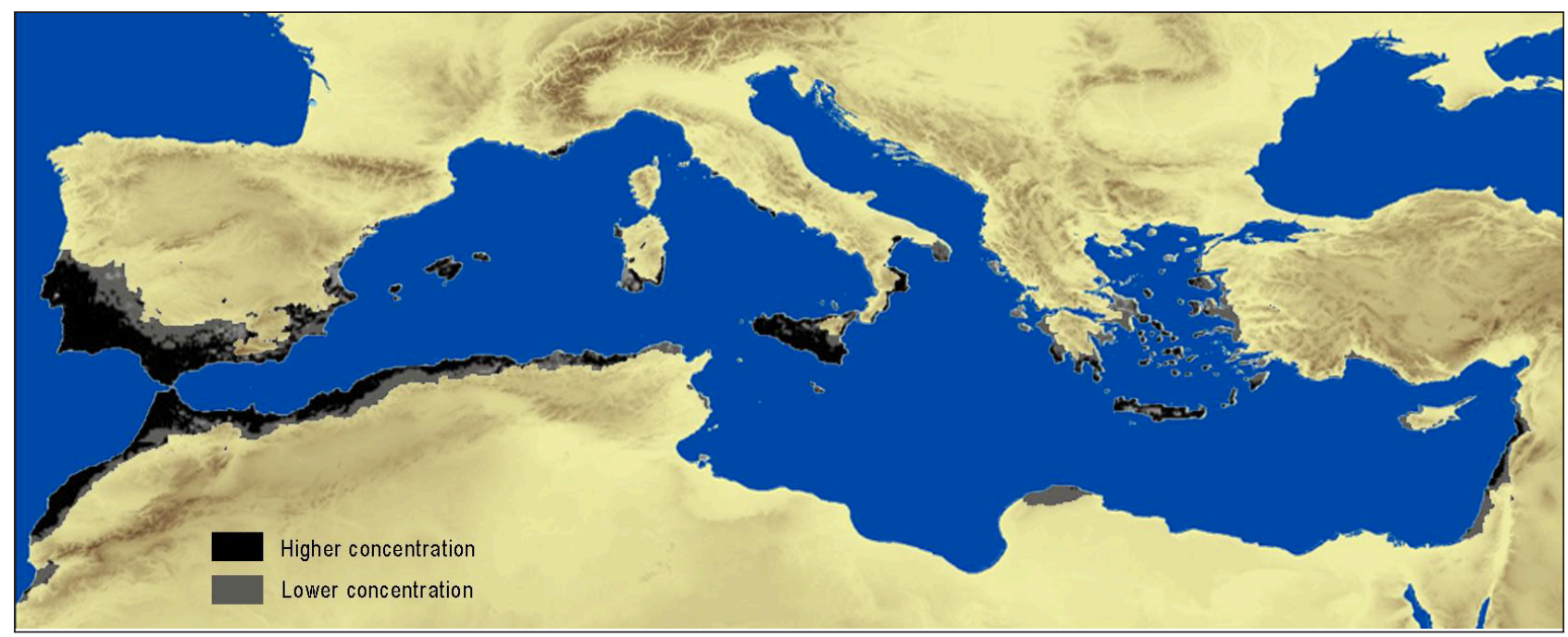

Figure 7. Suitable areas for Chamaerops humilis, estimated in the last interglacial ( $\sim 120,000-140,000$ years BP). Modified after Garcia-Castaño et al., 2014.

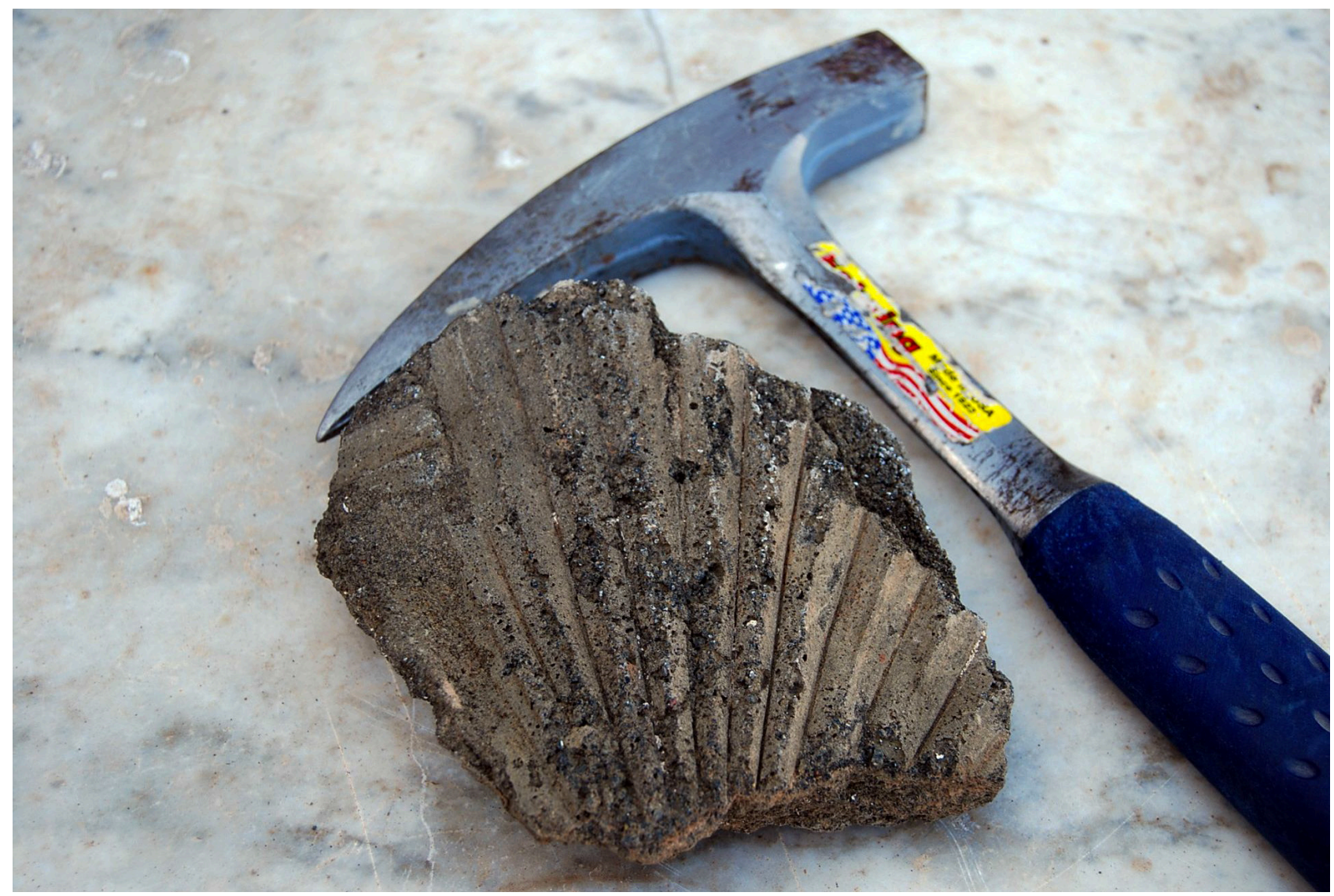

Figure 8. Chamaerops umilis leaves imbedded in the deposits of the Falconiera Tuff Cone pyroclastic surges at Tramontana.

rhizomatous, with palmate leaves [do Amaral Franco, 1980; Herrera, 1989; del Cañizo, 2011] and is characterized by variable life form, leaf colour, and by the presence of thorns [Maire, 1980]. Its optimum growing temperature is between $22-30^{\circ} \mathrm{C}$. The oldest fossil records of Chamaerops are from the Eocene in Europe [Palamarev, 1989] and it is considered one of the most ancient fleshy-fruited species in the Mediterranean basin [Palama- rev, 1989; Herrera, 1995]. Their fan-shaped leaves are so fibrous that the plants are quite readily preserved as fossils or prints, also within high-temperature pyroclastic density currents, as in the case of the Ustica specimens.

The first site of leaf-print discovery was on the eastern side of the Tramontana Plain, at about $50 \mathrm{~m}$ asl, in a manmade excavation, where a well-lithified succession of palagonitized grey tuffs from the Falco- 


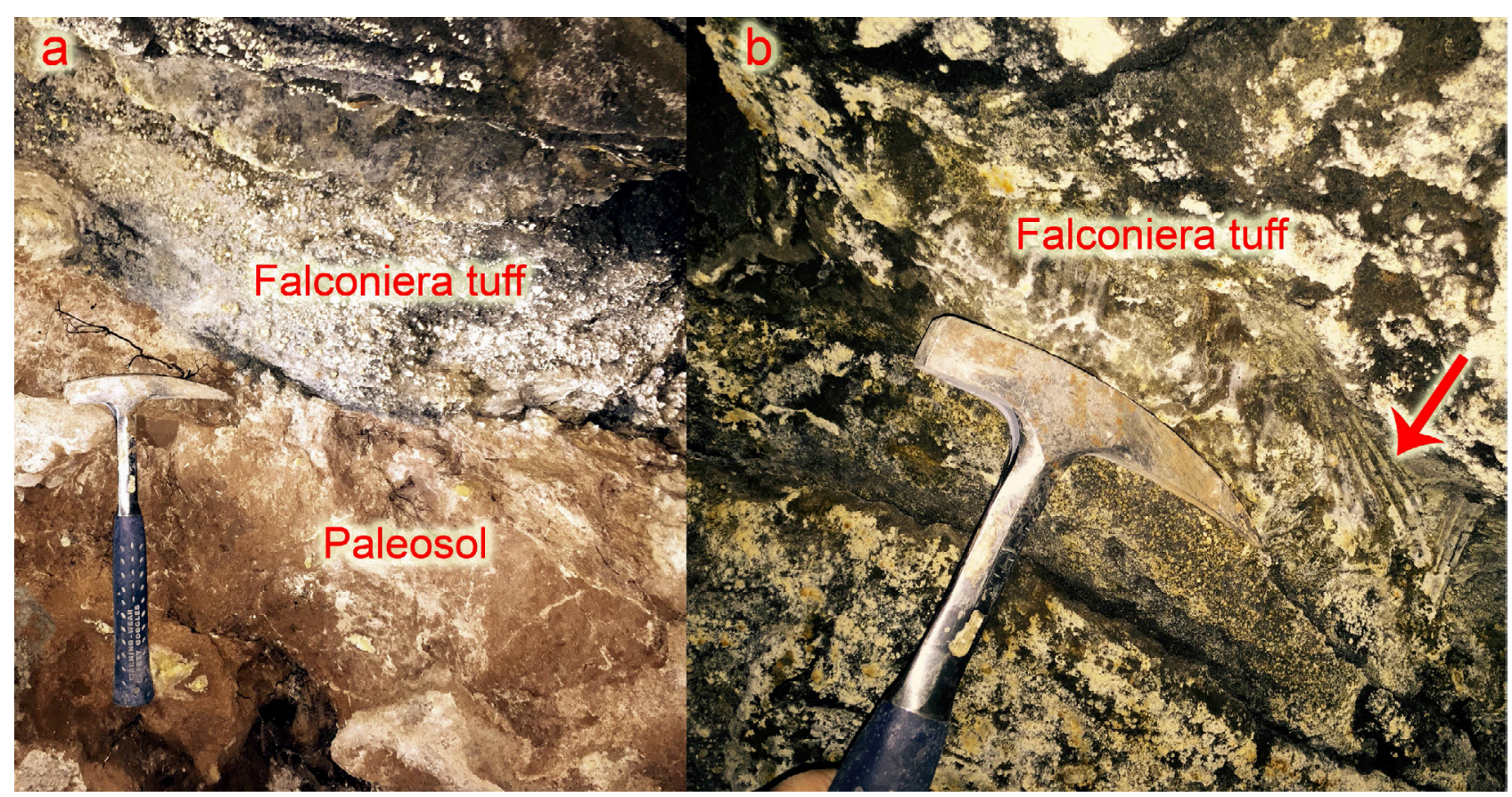

Figure 9. a) The paleosol and the overlying Falconiera tuff at Torre S. Maria (western periphery of Ustica village); b) the Chamaerops humilis leaves and branches, embedded in the base of the tuffs (red arrow).

niera eruption outcrops. This is one of the most distal outcrops of this unit, although the exposed succession is still more than $1 \mathrm{~m}$ thick and characterized by a westward low-angle dip. Numerous leaf prints have been found in this site (Figure 8), and some of them are visible in bricks used for the building of perimeter walls that separate adjacent farms.

The second outcrop is located at about $60 \mathrm{~m}$ asl in a cave converted into a water tank in ancient times, but presently not used. A thick and immature paleosol, varying irregularly in color from light brown at the top to yellowish at the base (Figure 9a) is exposed inside the cave. The Falconiera tuff layers overlie this paleosol, on which Chamaerops flourished. The remnants of abundant leaf and stem prints are widely distributed at the contact between the paleosol and the tuff (Figure 9b).

\section{Discussion and conclusion}

Tuff cones are usually monogenetic volcanoes, typically constructed during phreatomagmatic eruptions, in which surface water (lake or shallow-marine) is located above the vent [Cas and Wright, 1987]. The Falconiera tuff-cone succession shows a quasi-regular alternation of fine-grained, plane-parallel and cross-stratified base surge deposits, and massive to crudely stratified, coarse-ash surge and scoria fallout deposits. This kind of succession can be interpreted as the product of a pulsating energy during the eruption, in which water gained periodic access to the volcanic conduit. This generated a series of closely-timed repetitive explosions that emplaced base surge deposits, that dispersed radially away from the vent, up to a distances $<1 \mathrm{~km}$. Each phreatomagmatic explosion was followed by magmatic explosions that resulted in the scoria fallout layers intercalated in the succession and partially eroded by further surge-beds. The presence of lavas and welded scoriae at the bottom of the crater suggests a general progression from phreatomagmatic to Strombolian or Hawaiian and effusive activity over time, likely representing the ponding of degassed lava, and the occurrence of occasional low-energy magmatic explosions, close to the end of the eruption. This also suggests a decrease in the water-magma interaction or the water-magma ratio toward the end of the eruption, when magma could have been cut off from the water supply, due to the emplacement of the surge beds and the construction of the cone.

The Falconiera eruption is likely to have occurred in a shallow marine environment, close to the coastline, as also testified by the sedimentary deposits lying at the base of the tuffs: the basal contact of the tuffs indicates that the lowermost surge beds were emplaced across shallow marine or beach deposits in the area close to the vent (Falconiera northern slope and Cala del Camposanto; Figure 4) and above a paleosol with palm leaf prints, and therefore in a continental environment, in more distal westernmost areas (Tramontana plain and Torre S. Maria; Figure 4); and again above beach and reef deposits in a shallow marine en- 


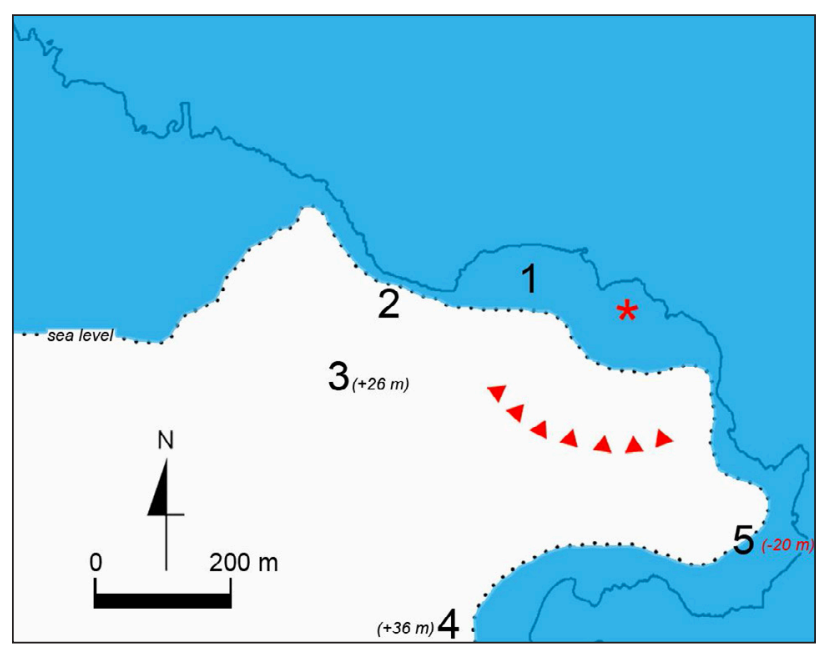

Figure 10. Reconstructed coastline at the time of the Falconiera eruption, and inferred elevation and depth of some points (see text for explanation). Numerals refer to the measured section of Fig. 4. The present coastline is reported for reference as a continuous blue line. Red triangles: Falconiera crater rim; asterisk: eruption vent.

vironment, in southeasternmost proximal areas (Mezzaluna; Figure 4). Thus, interesting inferences about the palaeoenvironment at the time of the eruption can be drawn from the presence of Cladocora caespitosa corals. Cladocora caespitosa is a scleractinian coral living in the Mediterranean Sea from 5-40 m depth in turbid environments [Laborel, 1961; Zibrowius, 1980]. Large fossil formations of Cladocora caespitosa have been dated since the Late Pliocene characterizing the warmer climatic phases of the Pleistocene when this coral formed true reefs in both the eastern and western Mediterranean Sea [Peirano et al., 2004]. However, recent studies on the responses of these corals to sea-water warming demonstrated that if the water temperature exceeds $24-28{ }^{\circ} \mathrm{C}$ for prolonged time periods (several days), only those colonies that live at depths greater than $15 \mathrm{~m}$ can survive [Kersting et al., 2013]. Considering that the MIS 5.5 was characterized by a tropical climate in the Mediterranean, it can be inferred that the Cladocora caespitosa colony of the Mezzaluna outcrop lived between 15 and $40 \mathrm{~m}$ bsl. This inference fits well with the position of the Mezzaluna beach deposit, found at an elevation of $30 \mathrm{~m}$ asl, is that about $15-20 \mathrm{~m}$ above the Cladocora caespitosa reef. The information on the depositional environment of the Falconiera tuffs, neatly constrains the trend of the coastline at the time of the eruption to a narrow strip at the margin between continental and beach/marine deposits, in the northeastern sector of the island (Figure 10). Moreover, because during MIS 5.5 the sea level was about $6 \mathrm{~m}$ higher than present [Ferranti et al., 2006] and beach deposits formed during this isotopic stage are presently displaced at about
$30 \mathrm{~m}$ asl, a total uplift of about $24 \mathrm{~m}$ over the past 130 $\mathrm{ky}$ can be estimated. Therefore, it is possible to assume that the two Chamaerops humilis sites of Tramontana and Torre S. Maria were located at about 26 and $36 \mathrm{~m}$ above the Eutyrrhenian sea level respectively, not very far from the coastline (Figure 10).

As in the case of many other similar volcanoes [Vespermann and Schmincke, 2000; Solgevik et al., 2007; Di Vito et al, 1999 and references therein; Kereszturi and Nemeth, 2012 and references therein; Coltelli et al., 2016] the Falconiera eruption could have lasted from weeks to months (including the Hawaiian/ Strombolian and effusive final phases), leading to the formation of a typically asymmetric edifice, which later collapsed and opened toward the sea, as already observed for other coastal tuff-cones [Vespermann and Schmincke, 2000; Solgevik et al., 2007; Di Vito et al, 1999 and references therein]. The survival time of these edifices in areas exposed to the erosional action of the sea can be very short, in the order of few weeks or months, as demonstrated for similar island or coastal volcanoes [Solgevik et al., 2007; Falzone et al., 2009; Coltelli et al., 2016]. In the case of the Falconiera tuff-cone, we infer that sea-water gained access to the crater in a relatively brief time interval, after the end of the eruption, dismantling the northern side of the edifice and abrading the floor of the crater, leaving a flat level surface (Figure 3a) and a thin veneer of very shallow marine and beach deposits. As already stated, both the present elevation of the level surface and the fossil content are the same in the Euthyrrenian marine terrace and deposits that underlie the Falconiera products. The same occurred along the southern side of the Falconiera promontory, at Mezzaluna, where the fossil assemblage discovered by Buccheri et al. [2014] in the marine deposits above the surge beds testifies that the normal sedimentary conditions where quite soon re-established after the eruption. There is no evidence that significant time elapsed between the eruption and the recolonization of the impacted continental environment.

Based on the volcanological, stratigraphical, geomorphological and palaeontological data outlined above, it seems reasonable that the Falconiera tuff-cone eruption had a very local and limited impact on the environment: the products were emplaced at the transition between land and sea, in both marine and continental environments, up to a distance of less than 1 $\mathrm{km}$ from the vent. The volcanic edifice built on by the eruption slightly modified the coastline (Figure 10), adding a small promontory to the profile of the island, 
which was partly dismantled seaward in a short period. Although the products from the eruption buried beach deposits rich in mollusks, colonies of corals and subaerial plants, it seems that, at least in the submarine habitat, the pre-eruptive sedimentary and biological conditions were quickly re-established, testifying to a strong environmental resilience to the local abrupt change imposed by the eruption.

Acknowledgements. The authors are grateful to Laura Sadori (University of Rome "La Sapienza") for the determinations on fossil leaf prints. Ilenia Arienzo (INGV - Osservatorio Vesuviano) is thanked for the chemical analyses on a tuff sample, which confirmed its attribution to the Falconiera unit. Prof. Antonella Carrubba is warmly thanked for the revision of the English version of the manuscript. A special thanks is due to Giovanni Palmisano for making available his specimens of leaf prints, and to Sabino Palmisano, which allowed us access to the cave in which many leaf prints were found. We are grateful to two anonymous reviewers, whose comments and suggestions improved our manuscript.

\section{References}

Barberi, F. and F. Innocenti (1980). Volcanisme Neogéne et Quaternaire. Guide a l'excursion 122-A, Soc. It. Miner. Petrol., 99-104.

Barberi, F., S. Borsi, G. Ferrara and F. Innocenti (1969). Strontium isotopic composition of some recent basic volcanites from southern Tyrrhenian sea and Sicily Channel, Contr. Mineral. And Petrol., 23, 157172.

Bellia, S., S. Hauser and S.G. Rotolo (2000). Petrochemical characterization of some submarine shoals of the Island of Ustica, Mem. Soc. Geol. It., 55, 321-324.

Buccheri, G., C. D’Arpa and F. Foresta Martin (2014). A geosite to be saved: the Tyrrhenian fossil deposit on the island of Ustica, Naturalista Sicil., S. IV, XXXVIII, 179-191.

Cas, R.A.F. and J.V. Wright (1987). Volcanic successions Modern and ancient, a geological approach to processes, products and successions, Chapman and Hall, London, Weinheim, New York, Tokyo, Melbourne, Madras, $528 \mathrm{pp}$.

Cinque, A., L. Civetta, G. Orsi and A. Peccerillo (1988). Geology and geochemistry of the island of Ustica (Southern Tyrrhenian sea), Rend. Soc. It. Min. e Petr., 43, 987-1002.

Coltelli, M., D. Cavallaro, G. D’Anna, A. D'Alessandro, F. Grassa, G. Mangano, D. Patanè and S. Gresta (2016). Exploring the submarine Graham Bank in the Sicily Channel, Ann. Gephys., 59 (2), S02008, 1-13.

del Cañizo, J.A. (2011). Palmeras, 3rd ed. Madrid, Spain: Ediciones Mundi-Prensa, 1150 pp. de Vita, S. (1993). Assetto geologico-strutturale ed evoluzione vulcanologica dell'isola di Ustica (stratigrafia, tettonica e meccanismi eruttivi), $\mathrm{PhD}$ Thesis, Napoli, 162 pp.

de Vita, S. and G. Orsi (1994). I terrazzi marini dell'isola di Ustica (Mar Tirreno Meridionale, Italia), Mem. Descr. Carta Geol. D’It., 52, 405-406.

de Vita, S., G. Guzzetta and G. Orsi G (1995). Deformational features of the Ustica volcanic area in the Southern Tyrrhenian Sea (Italy), Terra Nova, 7, 623-629.

de Vita, S., M.A. Laurenzi, G. Orsi and M. Voltaggio (1998). Application of 40Ar/39Ar and 230Th dating methods to the chronostratigraphy of Quaternary basaltic volcanic areas: the Ustica island case history, Quat. Int., 47/48, 117-127.

Di Vito, M.A., R. Isaia, G. Orsi, J. Southon, S. de Vita, M. D’Antonio, L. Pappalardo and M. Piochi (1999). Volcanism and deformation since 12,000 years at the Campi Flegrei caldera (Italy), J. Volcanol. Geotherm. Res., 91 (2-4), 221-246.

do Amaral Franco, J. (1980). Chamaerops. In: Tutin TG, Heywood VH, Burges NA, Moore DM, Valentine DH, Walters SM, Webb DA, editors.Flora Europaea, Vol. V. Cambridge, UK: Cambridge University Press, p. 267.

Falzone, G., G. Lanzafame and P.L. Rossi (2009). Il vulcano Ferdinandea nel Canale di Sicilia, Geoitalia, 29, 15-20.

Fedriani, J. M. and M. Delibes (2011). Dangerous liaisons disperse the Mediterranean dwarf palm: fleshy-pulp defensive role against seed predators, Ecology, 92, 304-315.

Ferranti, L., F. Antonioli, B. Mauz, A. Amorosi, G. Dai Pra, G. Mastronuzzi, C. Monaco, P. Orrù, M. Pappalardo, U. Radtke, P. Renda, P. Romano, P. Sanso and V. Verrubbi (2006). Markers of the last sea-level high stand along the coast of Italy: tectonic implications, Quat. Int., 145-146, 30-54.

Garcia-Castaño, J.L., A. Terrab, M.A. Ortiz, T.F. Stuessy and S. Talavera (2014). Patterns of phylogeography and vicariance of Chamaerops humilis L.(Palmae). Turk. Jour. Bot,, 38(6), 1132-1146.

Giese, P. and C. Morelli (1973). La struttura della crosta terrestre in Italia, Acc. Naz. Lincei, 183, 317-362.

Herrera, C.M. (1995). Dispersal systems in the Mediterranean: ecological, evolutionary, and historical determinants, Annual Review of Ecology and Systematics, 26, 705-727.

Herrera, J. (1989). On the reproductive biology of the dwarf palm, Chamaerops humilis in Southern 
Spain, Principes 33, 27-32.

Kereszturi, G., and K. Németh (2012). Monogenetic basaltic volcanoes: genetic classification, growth, geomorphology and degradation, INTECH Open Access Publisher.

Kersting, D. K., N. Bensoussan and C. Linares (2013). Long-term responses of the endemic reef-builder Cladocora caespitosa to Mediterranean warming, PLoS One, 8(8), e70820.

Kindler, P., E. Davaud and A. Strasser (1997). Tyrrhenian coastal deposits from Sardinia (Italy): a petrographic record of high sea levels and shifting climate belts during the last interglacial (isotopic substage 5e), Pal. Pal. Pal., 133, 1-25.

Laborel, J. (1961). Sur un cas particulier de concrétionnement animal. Concrétionnement à Cladocora caespitosa L. dans le Golfe de Talante, Rapp. PV Réun CIESM, 16(2), 429-432.

Maire, R. (1980). Flore de L'Afrique du Nord, Vol. XV. Paris, France: L’Imprimerie Jouve pour les Éditions Lechevalier S.A.R.L.

Médail, F. and P. Quézel (1996). Signification climatique et phyto-écologique de la redécouverte en France méditerranéenne de Chamaerops humilis L. (Palmae). Comptes rendus de l'Académie des sciences (Paris), Sciences de la vie, 319, 139-45.

Palamarev, E. (1989). Paleobotanical evidences of the Tertiary history and origin of the Mediterranean sclerophyll dendroflora, Plant Syst. Evol., 162(1), 93-107.

Peccerillo, A. (2005). Plio-quaternary volcanism in Italy (Vol. 365). Springer-Verlag Berlin Heidelberg, $365 \mathrm{pp}$.

Peirano, A., C. Morri, C.N. Bianchi, J. Aguirre, F. Antonioli, G. Calzetta, L. Carobene, G. Mastronuzzi and P. Orrù (2004). The Mediterranean coral Cladocora caespitosa: a proxy for past climate fluctuations? Global and Planet. Change, 40(1), 195-200.

Romano, R. and C. Sturiale (1971). L'isola di Ustica. Studio geo-vulcanologico e magmatologico. Riv. Min. Sic., 22, 127-129.

Ruggeri, G. and G. Buccheri (1968). Una malacofauna tirreniana dell'isola di Ustica (Sicilia), Geologica romana, 7, 27-57.

Shackleton, N. J., and N.D. Opdyke (1973). Oxygen isotope and palaeomagnetic stratigraphy of equatorial Pacific core V28-238: Oxygen isotope temperatures and ice volumes on a 105 year and 106 year scale. Quat. Res., 3(1), 39-55.

Solgevik, H., H. Mattsson and O. Hennelin (2007). Growth of an emergent tuff cone: Fragmentation and depositional processes recorded in the Capelas tuff cone, São Miguel, Azores, J. Volcanol. Geotherm. Res., 159, 246-66.

Trua, T., G. Serri and M. Marani (2003). Lateral flow of African mantle below the nearby Tyrrhenian plate: geochemical evidence, Terra Nova, 15, 433-440.

Vespermann, D. and H.U. Schmincke (2000). Scoria cones and tuff rings, in Sigurdsson, H. (Ed.) The Encyclopedia of volcanoes. Academic Press, San Diego, pp. 683-694.

Zibrowius, H. (1980). Les Scleractiniaires de la Méditerranée et del Atlantique nord-oriental. Mem. Inst. Oceanogr. Monaco, 11, 1-284.

${ }^{\star}$ Corresponding author: Sandro de Vita Istituto Nazionale di Geofisica e Vulcanologia Sezione di Napoli Osservatorio Vesuviano, Napoli, Italy. e-mail: sandro.devita@ingv.it

by Istituto Nazionale di Geofisica e Vulcanologia. All rights reserved 